\title{
Acute Lymphoid Leukemia After Anti-TNF-alpha Treatment: A Case Report and Review of the Literature
}

\author{
Füsun GEDİZ ÖZDEMİRKIRAN, ${ }^{1}$ Bahriye Kadriye PAYZIN,${ }^{1}$ Eyüp ÇOBAN, ${ }^{2}$ \\ Korhan Barış BAYRAM, ${ }^{3}$ Betül KÜÇÜKZEYBEK ${ }^{4}$ \\ ${ }^{1}$ Department of Hematology, Katip Çelebi University, Atatürk Training and Research Hospital, İzmir, Turkey \\ ${ }^{2}$ Department of Internal Medicine, Katip Çelebi University, Atatürk Training and Research Hospital, İzmir, Turkey \\ ${ }^{3}$ Department of Physical Medicine and Rehabilitation, Katip Çelebi University, Atatürk Training and Research Hospital, İzmir, Turkey \\ ${ }^{4}$ Department of Pathology, Katip Çelebi University, Atatürk Training and Research Hospital, Izmir, Turkey
}

\section{ABSTRACT}

The efficacy and safety of anti-tumor necrosis factor-alpha drugs have been shown in active ankylosing spondylitis cases that are resistant to traditional disease-modifying antirheumatic drugs. However, it is well known that these drugs may cause some complications as reactivation of tuberculosis and various hematologic malignancies. In this article, we report a 40-year-old male patient with ankylosing spondylitis who developed Philadelphia chromosome-positive acute lymphoid leukemia after treatment with tumor necrosis factor-alpha inhibitors.

Keywords: Acute lymphoid leukemia; ankylosing spondylitis; anti-tumor necrosis factor-alpha drugs.

Ankylosing spondylitis (AS) is a chronic systemic inflammatory disease of unknown etiology which primarily targets sacroiliac and axial joints. Major improvements have been achieved in its treatment since the last decade. ${ }^{1}$ The efficacy of anti-tumor necrosis factor-alpha (anti-TNF- $\alpha$ ) treatment has been shown in patients with resistance to traditional antirheumatic drugs. ${ }^{2}$ They are effective both in controlling the clinical, laboratory and radiological findings and improving the functional capacity and quality of life. However, this may be accompanied by various side effects (infection, demyelinating disease, reactivation of tuberculosis and etc. $)^{2}$ including the risk of causing and/or triggering malignancies. In recent years, hematologic malignancies such as lymphoma, acute myeloid leukemia (AML) and acute lymphoid leukemia (ALL) after various anti-TNF- $\alpha$ therapies have been reported. ${ }^{3}$ Herein, we reported a
Philadelphia chromosome-positive (Ph+) ALL patient with AS after the treatment of anti-TNF- $\alpha$ (etanercept and adalimumab).

\section{CASE REPORT}

A 40-year-old male was referred to our clinic with leukocytosis, anemia, and thrombocytopenia. He presented with back pain, weakness and weight loss in 2002, and was diagnosed with AS. The patient was given sulphasalazine $2 \mathrm{~g} /$ day and indomethacin $100 \mathrm{mg} /$ day, and followed with control visits for nine years. In April 2011, an anti-TNF- $\alpha$ (etanercept) treatment $(50 \mathrm{mg} /$ week) was started because of disease activation and unresponsiveness to currently used drugs. In January 2012, treatment was switched to adalimumab (40 mg/2 week) for poor response.

Received: May 18, 2015 Accepted: September 03, 2015 Published online: October 05, 2015

Correspondence: Füsun Gediz Özdemirkıran, MD. Katip Çelebi Üniversitesi Atatürk Eğitim ve Araştırma Hastanesi Hematoloji Kliniği, 35360 Basın Sitesi, İzmir, Turkey. Tel: +90 232 - 3707485 e-mail: mdfusun@gmail.com

@2015 Turkish League Against Rheumatism. All rights reserved. 
In November 2012, the patient was referred to our Hematology Department with progressive fatigue, joint pain, and asthenia. Physical examination showed significant pallor and palpable spleen $5 \mathrm{~cm}$ below the costal margin. According to clinical and laboratory results, the patient was diagnosed with $\mathrm{Ph}+\mathrm{ALL}$. He was given imatinib mesylate (a tyrosine-kinase inhibitor) $400 \mathrm{mg} /$ day and induction ALL regimen (including glucocorticoid, vincristine, anthracycline and asparaginase). $\mathrm{He}$ developed invasive fungal pneumonia during the induction treatment. Despite the broadspectrum antibiotherapy, the patient died due to sepsis and respiratory failure.

\section{DISCUSSION}

In recent years, anti-TNF- $\alpha$ drugs have revolutionized the treatment of AS and made significant clinical, laboratory and radiological remission possible. However, the widespread and efficient use of anti-TNF- $\alpha$ treatment has brought along a great number of questions and discussions. To our knowledge, Brown et al. ${ }^{4}$ were the first to report lymphoma development after anti-TNF- $\alpha$ treatment in 2002. Since then, anti-TNF- $\alpha$ treatment and malignancy development have been investigated more thoroughly. Although anti-TNF- $\alpha$ antibodies were shown to increase hematologic malignancy incidences in some studies, ${ }^{5}$ no positive correlation was found in others. ${ }^{3}$ In a metaanalysis of nine randomized controlled studies, ${ }^{5}$ 3,943 rheumatoid arthritis patients were treated with infliximab/adalimumab and malignancy risk was found 3.3 times of normal population and significantly more common with higher doses of anti-TNF- $\alpha$. However, this study is criticized about inhomogeneity among randomization groups, and treatment durations and agents. Another comprehensive study including 18,572 rheumatoid arthritis patients ${ }^{6}$ indicated an increased risk of lymphoma with anti-TNF- $\alpha$ treatment. On the other hand, a recent study in AS and psoriatic arthritis cases found no correlation between lymphoma risk and antiTNF- $\alpha$ treatment. $^{7}$

In the literature, acute leukemia cases due to anti-TNF- $\alpha$ treatment were also reported; however, not as much as lymphoma. ${ }^{8-16}$ First case was published in 2003. ${ }^{8}$ The Food and Drug Administration declared 44 AML cases which

Table 1. Clinical characteristics of patients developing acute leukemia after anti-tumor necrosis factor-alpha treatment

\begin{tabular}{|c|c|c|c|c|c|c|c|c|c|}
\hline No & Reference & $\begin{array}{l}\text { Age/gender } \\
\text { (years) }\end{array}$ & Diagnosis & $\begin{array}{l}\text { Disease } \\
\text { duration } \\
\text { (years) }\end{array}$ & $\begin{array}{l}\text { Type of } \\
\text { leukemia }\end{array}$ & $\begin{array}{c}\text { Type of } \\
\text { anti-TNF- } \alpha\end{array}$ & $\begin{array}{c}\text { Duration of } \\
\text { anti-TNF- } \alpha \\
\text { treatment } \\
\text { (months) }\end{array}$ & $\begin{array}{l}\text { Time to } \\
\text { diagnosis of } \\
\text { leukemia } \\
\text { (months) }\end{array}$ & $\begin{array}{l}\text { Prior } \\
\text { treatment }\end{array}$ \\
\hline 1 & Hellgren et al. ${ }^{7}$ & $31 / \mathrm{F}$ & AS & 15 & AML-M2 & Etanercept & 4 & 4 & SSZ, AZA \\
\hline 2 & Ozen et al. ${ }^{17}$ & $40 / \mathrm{M}$ & CD & 4 & $\mathrm{Ph}+\mathrm{ALL}$ & Infliximab & 1.5 & 6 & MTX, AZA \\
\hline 3 & Alert $^{9}$ & $57 / \mathrm{M}$ & PsA & $\begin{array}{l}\text { Since } \\
\text { childhood }\end{array}$ & AML & Etanercept & 9 & 14 & Steroids \\
\hline 4 & Bachmeyer et al. ${ }^{11}$ & $40 / \mathrm{M}$ & Psoriasis & 10 & AML-M2 & Etanercept & 4 & 4 & \\
\hline 5 & Saba et al. ${ }^{12}$ & $44 / \mathrm{F}$ & JRA & $\begin{array}{l}\text { Since } \\
\text { childhood }\end{array}$ & AML & Adalimumab & 6 & 6 & $\begin{array}{c}\text { MTX, LFN, breast } \\
\text { carcinoma } \\
\text { chemotherapy }\end{array}$ \\
\hline 6 & Lekpa et al. ${ }^{13}$ & $60 / \mathrm{M}$ & AS & 8 & AML-M5 & Infliximab & 78 & 78 & \\
\hline 7 & Cesarini et al. ${ }^{19}$ & $63 / F$ & $\mathrm{CD}$ & 23 & $\mathrm{Ph}+\mathrm{ALL}$ & Adalimumab & 6 & 6 & AZA, steroids \\
\hline 8 & Knudson et al. ${ }^{14}$ & $43 / \mathrm{M}$ & Psoriasis & $\begin{array}{l}\text { Not } \\
\text { known }\end{array}$ & AML & Etanercept & 15 & $\begin{array}{c}36 \\
\text { (MDS within } 14 \text { months) }\end{array}$ & \\
\hline 9 & Min et al. ${ }^{15}$ & $45 / M$ & AS & 10 & AML & Adalimumab & 3 & 3 & MTX, HQ \\
\hline 10 & Sadlier et al. ${ }^{16}$ & $67 / \mathrm{M}$ & CLV & 9 & AML & Etanercept & 26 & $\begin{array}{c}26 \\
\text { (MDS within } 16 \text { months) }\end{array}$ & $\begin{array}{l}\text { AZA, MMF, } \\
\text { MTX }\end{array}$ \\
\hline 11 & Ozen et al. ${ }^{17}$ & $56 / \mathrm{M}$ & CD & 4 & AML-M2 & Adalimumab & 2 weeks & 2 weeks & $\begin{array}{l}\text { AZA, SSZ, } \\
\text { steroids }\end{array}$ \\
\hline 12 & Ozen et al. ${ }^{17}$ & $38 / \mathrm{M}$ & AS, CD & $7-2 ?$ & APL & $\begin{array}{l}\text { Etanercept } \\
\text { Infliximab }\end{array}$ & $12+18$ months & $30(12+18)$ & AZA, SSZ \\
\hline 13 & Our study & $40 / \mathrm{M}$ & AS & 10 & $\mathrm{Ph}+\mathrm{ALL}$ & $\begin{array}{c}\text { Etanercept } \\
\text { Adalimumab }\end{array}$ & $10+9$ months & $19(10+9)$ & SSZ \\
\hline
\end{tabular}


developed under the treatment of anti-TNF- $\alpha$ drugs. No details of subtypes, survival, or demographic data were given. ${ }^{9}$ The relevant case reports about acute leukemia after anti-TNF- $\alpha$ treatment published on MEDLINE are reviewed in Table $1^{10-16}$ Ten of the 13 reported patients who developed acute leukemia after anti-TNF- $\alpha$ had AML. AML development may be attributed to higher incidence of this disorder in adults; however, $\mathrm{Ph}$ chromosome positivity in all of the three ALL cases is interesting. A first case of Ph+ ALL in a patient receiving anti-TNF- $\alpha$ (infliximab) was described in 2003. ${ }^{18}$ Then, Cesarini et al. ${ }^{19}$ reported a second case in a patient receiving adalimumab in 2010. According to our knowledge, our Ph+ ALL patient represents the third case in the literature that developed in a patient treated with anti-TNF- $\alpha$ drugs.

On the other hand, reports have been published about the risk of hematological malignancies in human leukocyte antigen-B27 carriers. ${ }^{20}$ As human leukocyte antigen-B27 positivity was higher in patients with AML and ALL, human leukocyte antigen-B27 carriers have an increased risk of acute leukemia. Therefore, concomitant AS might lead predisposition to lymphoid malignancies. TNF- $\alpha$ is a cytokine with antitumor activity. In animal studies, its anti-cancer activity by triggering $\mathrm{T}$-cell mediated immunity and selective destruction of blood vessels was shown. ${ }^{21}$ However, low physiological levels of TNF- $\alpha$ may lead to cancer, tumor growth, and metastasis directly and/or mediated by chemokine network.

In conclusion, this article reports $\mathrm{Ph}+\mathrm{ALL}$ in a patient using anti-TNF- $\alpha$ treatment for AS. The relationship between anti-TNF- $\alpha$ and malignancies is controversial. Inconsistent results may be explained by various reasons such as patient selection, duration of disease, family history and using another antirheumatic drug. There might be other factors including interaction with other molecules that play a role in the etiopathogenesis of diseases, environmental and genetic factors, which require further studies.

\section{Declaration of conflicting interests}

The authors declared no conflicts of interest with respect to the authorship and/or publication of this article.

\section{Funding}

The authors received no financial support for the research and/or authorship of this article.

\section{REFERENCES}

1. Davis JC Jr, van der Heijde DM, Braun J, Dougados M, Clegg DO, Kivitz AJ, et al. Efficacy and safety of up to 192 weeks of etanercept therapy in patients with ankylosing spondylitis. Ann Rheum Dis 2008;67:346-52.

2. Reed MR, Taylor AL. Tumour necrosis factor inhibitors in ankylosing spondylitis. Intern Med J 2008;38:781-9.

3. Askling J, Fored CM, Baecklund E, Brandt L, Backlin C, Ekbom A, et al. Haematopoietic malignancies in rheumatoid arthritis: lymphoma risk and characteristics after exposure to tumour necrosis factor antagonists. Ann Rheum Dis 2005;64:1414-20.

4. Brown SL, Greene MH, Gershon SK, Edwards ET, Braun MM. Tumor necrosis factor antagonist therapy and lymphoma development: twenty-six cases reported to the Food and Drug Administration. Arthritis Rheum 2002;46:3151-8.

5. Bongartz T, Sutton AJ, Sweeting MJ, Buchan I, Matteson EL, Montori V. Anti-TNF antibody therapy in rheumatoid arthritis and the risk of serious infections and malignancies: systematic review and meta-analysis of rare harmful effects in randomized controlled trials. JAMA 2006;295:2275-85.

6. Wolfe F, Michaud K. Lymphoma in rheumatoid arthritis: the effect of methotrexate and anti-tumor necrosis factor therapy in 18,572 patients. Arthritis Rheum 2004;50:1740-51.

7. Hellgren K, Smedby KE, Backlin C, Sundstrom C, Feltelius N, Eriksson JK, et al. Ankylosing spondylitis, psoriatic arthritis, and risk of malignant lymphoma: a cohort study based on nationwide prospectively recorded data from Sweden. Arthritis Rheumatol 2014;66:1282-90.

8. Bakland G, Nossent H. Acute myelogenous leukaemia following etanercept therapy. Rheumatology (Oxford) 2003;42:900-1.

9. Alert F. Tumor Necrosis Factor (TNF) Blockers (marketed as Remicade, Enbrel, Humira, Cimzia, and Simponi). FDA Alert [Access: August 04, 2009].

10. Nair B, Raval G, Mehta P. TNF-alpha inhibitor etanercept and hematologic malignancies: report of a case and review of the literature. Am J Hematol 2007;82:1022-4.

11. Bachmeyer $\mathrm{C}$, Thiolière $\mathrm{B}$, Khosrotehrani K, Cattan E. Acute myelogenous leukemia in a patient receiving etanercept for psoriasis. J Am Acad Dermatol 2007;56:169-70.

12. Saba NS, Kosseifi SG, Charaf EA, Hammad AN. Adalimumab-induced acute myelogenic leukemia. South Med J 2008;101:1261-2. 
13. Kemta Lekpa F, Zahra K, Pautas C, Maury S, Chevalier X, Claudepierre P. Acute myeloid leukemia after infliximab: a case report. Clin Exp Rheumatol 2009;27:999-1000.

14. Knudson RM, Tefferi A, Pittelkow MR, Davis MD. Development of myelodysplastic syndrome evolving to acute myeloid leukemia in a patient receiving etanercept for psoriasis. J Am Acad Dermatol 2011;65:673-4.

15. Min HK, Lee JH, Koh E, Heo JY, Min JK, Park SH. A case of acute myeloid leukemia after adalimumab treatment in psoriatic arthritis. $J$ Rheum Dis 2012;19:91-4.

16. Sadlier M, Connaghan G, Kirby B. Acute myeloid leukemia presenting with cutaneous infiltrates in a patient receiving etanercept for chronic lymphocytic vasculitis. J Am Acad Dermatol 2012;67:264-5.

17. Özen M, Keskin O, Topçuoğlu P, Öztürk B, Özgül S,
Ilgen $\mathrm{U}$, et al. Autoimmune disease, tumor necrosis factor inhibitors and acute leukemia: possible associations in two patients? Leuk Lymphoma 2014;55:1697-8.

18. Alcaín G, Andrade RJ, Queipo de Llano MP, Moreno MJ, García-Cortés M, Franquelo E. Acute leukemia after infliximab therapy. Am J Gastroenterol 2003;98:2577.

19. Cesarini M, Vernia P, Angelucci E. Acute lymphoid leukemia in a Crohn's disease patient during treatment with adalimumab after a prolonged treatment with azathioprine and steroids. Inflamm Bowel Dis 2010;16:371-2.

20. Au WY, Hawkins BR, Cheng N, Lie AK, Liang R, Kwong YL. Risk of haematological malignancies in HLA-B27 carriers. Br J Haematol 2001;115:320-2.

21. Roberts NJ, Zhou S, Diaz LA Jr, Holdhoff $M$. Systemic use of tumor necrosis factor alpha as an anticancer agent. Oncotarget 2011;2:739-51. 